\title{
INCREASE OF TOTAL GLUTATHIONE AS A RESPONSE TO CD INDUCED STRESS IN A CHILEAN ENDEMIC BRYOPHYTES (THUIDIUM SP.)
}

\author{
GENNY LEINENWEBER ${ }^{I^{*}}$, SUSANA STEGEN ${ }^{l}$ AND PAULA DIAZ-PALMA ${ }^{1}$ \\ Departamento de Química, Facultad de Ciencias, Universidad Católica Del Norte, Avenida Angamos 0619* Antofagasta, Chile.
} (Received: March, 10, 2009 - Accepted: September 28, 2009)

\begin{abstract}
Bryophytes collected from the IV Region of Chile, were treated with $\mathrm{CdCl}_{2}$ to stimulate the synthesis of phytochelants. After cadmium treatment, total peptides were extracted from the plants and were analyzed using HPLC to search for the presence of phytochelatin molecules.

Chromatography results showed the absence of phytochelatin-like molecules in bryophytes. However, glutathione and a molecule suspected to be $\gamma$-glutamilcistein were detected. The latter compound is knowed to be involved in the metabolic pathway of the gluthatione and phytochelatin synthesis.

The results indicated the absence of detectable phytochelatins in bryophytes containing heavy metal as contaminants. The increase in glutathione during the experimental period may have been due to a response to oxidative stress. Thus this work suggests an important role of the glutathione in the detoxification mechanisms of bryophytes.
\end{abstract}

Key words: Bryophytes, glutathione, chromatography, oxidative stress.

\section{INTRODUCTON}

Contamination is currently one of the most studied phenomena. Elevated concentrations of heavy metals, of natural or anthropogenic origin, are one of the most difficult contaminants to study ${ }^{1}$. However there are organisms, like a large variety of plants, which are resistant to high levels of heavy metals 2,3 . Research in these organisms resistant to heavy metals have found the presence of compounds synthesized at intra-cellular level, which are capable of immobilizing these elements. Because of their ability to store metals, these organisms have been considered as an alternative to be used as bio-monitors or biological extractors at contaminated sites ${ }^{4,5,6,7}$.

The phytochelatins and the glutathione compose a class of compounds generated by plants in response to heavy metals. These phylochelatins are a family of peptides that have been identified in plants and some microorganisms. Phytochelatins have a primary structure of ( $\gamma$-glutamil- cysteine) $)_{\mathrm{n}}$ glycine, with $\mathrm{n}=2-118,9,10$. They are synthesized from glutathione, which is a tripeptide formed by glutamic acid, cysteine and glycine ( $\gamma$-glutamil-cisteinilglycine). Glutathione also plays an important role in the response of plants to environmental stress, oxidative stress and that produced by xenobiotic compounds such as heavy metals ${ }^{4,6,11}$. Phytochelatins have been described in different types of organisms such as plants, nematodes, algae and yeasts 3, 12. Some studies have demonstrated that bryophytes (mosses) do not form phylochelatins, but only their precursor glutathione ${ }^{5,11}$.

Considering that bryophytes have been described as organisms which are particularly reactive to contaminants and thus may have an important role as bio-indicators of environmental contamination ${ }^{5,13,14,15,16,17}$, this contribution examined the presence of phytochelants in endemic Chilean mosses challenged with a heavy metal, cadmium, by means of high-pressure liquid chromatography (HPLC).

\section{EXPERIMENTAL}

\section{Collection and maintenance of mosses}

Mosses were collected from the area of Alcohuas in the IV Region of Chile (Figure 1), at the northern limit of mosses geographic distribution in Chile. The collection site is located on the eastern shore of the Alcohuas River, an affluent of the Elqui River, the main river in the area. A large amount of spray is generated at the site, which keeps it humid and permits the development of numerous trees and shrubs. The luminosity is restricted, which makes it appropiated for the growth of mosses of only one genus, Thuidium sp.

Mosses were collected in October, 2005. Approximately, $7 \mathrm{~cm}^{2}$ of plants and soil were extracted from 10 different points scattered in the site. Samples were stored in hermetically sealed bags to preserve the humidity during the return to Antofagasta.

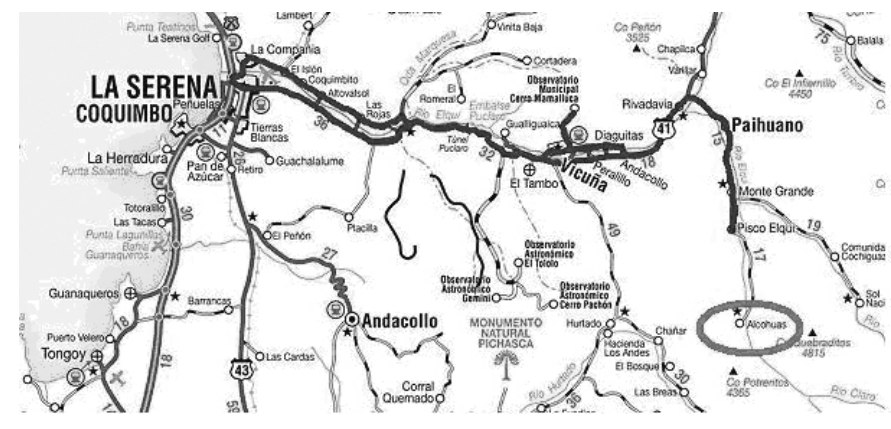

Figure 1: Map of the collection site of the moss Thuidium sp. Alcohuas (red circle) Valle de Elqui, IV Región, La Serena, Chile.

\section{Treatment of mosses with cadmium}

To induce the formation of phytochelants in moss plants, these were watered once daily with $100 \mu$ moles/L of $\mathrm{Cd}$ (II), for a period of 12 days. Previous studies with different species of mosses demonstrated that this concentration of Cadmium increased the GSH pool significantly ${ }^{11}{ }^{12}$. Plants were sprayed, since mosses absorb water through the cuticle.

Three samples of moss plants of $300 \mathrm{mg}$, were taken at day 0 (before watering with $\mathrm{Cd}), 4,7$ and 12 of exposition to the $\mathrm{Cd}$ solution according to the experimental design suggest by Bruns and col. ${ }^{11}$. Moss plants were cut and washed four times with supra-pure water (distilled and deionized), after removal of dry stems and soil. Plants were allowed to dry on paper towels at room temperature.

\section{Extraction of non-proteic thioles}

Non-proteic thioles were extracted using the protocol of Sneller and col. ${ }^{18}$, homogenizing $40 \mathrm{mg}$ of dry plant material in $2 \mathrm{ml}$ of a cold solution of DTPA (Fluka) $6.3 \mathrm{mM}$ and $0.1 \%(\mathrm{v} / \mathrm{v})$ TFA (Fluka). Mosses were ground in a porcelain mortar free of metals. The homogenized slurry was centrifuged at $10,000 \mathrm{~g}$. The supernatant was filtered with a $0.22 \mu \mathrm{m}$ nylon filter. Samples were stored refrigerated until use.

\section{Derivatization of sample with monobromobiane}

The buffer solution was $450 \mu 1$ of $200 \mathrm{mM}$ HEPPS $\mathrm{pH} 8.2$ containing DTPA $6.3 \mathrm{mM}$. DPTA was added to minimized GSH oxidation, reducing the potencial ability of $\mathrm{Cd}$ (II) to catalyze this reaction ${ }^{19}$. Then $10 \mu \mathrm{l}$ of a solution of $25 \mathrm{mM}$ monobromobimane dissolved in acetonitrile was added. To this mixture $250 \mu \mathrm{l}$ of sample was added, mixed and stored in the dark for $30 \mathrm{~min}$ at $45^{\circ} \mathrm{C}$. The reaction was stopped by adding $300 \mu \mathrm{l}$ of a $1 \mathrm{M}$ solution of metasulfonic acid (MSA) (Fluka). Samples were stored at $4^{\circ} \mathrm{C}$ until analysis by HPLC. Samples were derivatized and detected with a fluorescence detector ${ }^{19}$. 


\section{Chromatography}

A Kromasil Analytic Column of $60 \AA, 4.6 \mathrm{~mm}$ diameter and $25 \mathrm{~mm}$ length was used. Before injection, the column was equilibrated with methanol (Merck) and HPLC grade water (Merck) at $12 \%(\mathrm{v} / \mathrm{v})$ and $88 \%(\mathrm{v} / \mathrm{v})$, respectively, both containing $0.1 \%$ trifluoracetic acid (TFA, Merck) at a flow of $0.5 \mathrm{ml} / \mathrm{min}$. All solutions used were previously filtered with a GV membrane filter (Durapore) EM PDVF, $0.22 \mu \mathrm{m}$ pore size, $47 \mathrm{~mm}$ diameter.

A volume of derivatized sample was injected and the column was run in a slightly concave gradient of $12-25 \%(\mathrm{v} / \mathrm{v})$ of methanol for $15 \mathrm{~min}$, followed by a linear gradient of $25-35 \%(\mathrm{v} / \mathrm{v})$ of methanol from 15 to 29 min. Finally, a linear gradient of $35-50 \%(\mathrm{v} / \mathrm{v})$ of methanol was applied from 29 to $50 \mathrm{~min}$. The wavelength used for excitation was $380 \mathrm{~nm}$ and the emission wavelength was monitored at $470 \mathrm{~nm}^{18}$.

The compound N-acetyl-L-cysteine (Merck) was used to verify the derivatization process. Glutathione (Merck), a tripeptide composed of glutamic acid, cysteine and glycine was used as a standard for retention times.

\section{Determination of $\mathrm{Cd}$ in mosses}

Mosses without $\mathrm{Cd}$ and samples watered with $\mathrm{Cd}$ for 4, 7 and 12 days were washed with abundant deionized water $(18 \mathrm{M} \Omega)$ and dried at room temperature on absorbent towels. About $0,300 \mathrm{~g}( \pm 0,100 \mathrm{mg})$ of powdered and homogenized sample was treated with $5 \mathrm{ml}$ of concentrated $\mathrm{HNO}(65 \%$ suprapure), $4 \mathrm{ml}$ of $\mathrm{H}_{2} \mathrm{O}$ s.p. (18M 2 ) and $1 \mathrm{ml}$ of $\mathrm{H}_{2} \mathrm{O}_{2}(35 \%)$. To avoid crosscontamination, digestion vessels were previously cleaned in a bath of $10 \%$ $(\mathrm{v} / \mathrm{v})$ nitric solution for $48 \mathrm{~h}$.

Solutions were analyzed by flame atomic absorption spectrometry (AAS) (Perkin Elmer Model AANALYST 700) using an EDL lamp (discharge lamp without electrode). The detection limit ( $\mathrm{LOD}=0.010 \mu \mathrm{g} / \mathrm{ml}$ ) was calculated as the concentration corresponding to signals equal to three-times the standard deviation of 10 replicates of a blank solution. The standards of $\mathrm{Cd}$ used were of $0.5,1$ and $2 \mu \mathrm{g} / \mathrm{ml}$. A preparation with $1.5 \mu \mathrm{g} / \mathrm{ml}$ was used to test the calibration curve (quality control of the method). The accuracy (bias) and precision (\%RSD) of the methods were tested with certified reference materials: Spinach NBS $1570(2,84 \pm 0,07 \mathrm{mg} / \mathrm{kg})$ and Sea Lettuce BCR $279(0,274 \pm 0,035 \mathrm{mg} / \mathrm{kg})$. The results obtained for $\mathrm{Cd}(2,93 \pm 0,12$ and $0,263 \pm 0,12 \mathrm{mg} / \mathrm{kg}$ respectively) are in excellent agreement with the certified values, supported by the traceability test of $t$ Student. One sample of reference materials and blanks were included in each analytical batch and three parallel measurements were made in all cases.

The analytical precision and accuracy determined by quality assurance and quality control procedures using certified reference materials, a duplicate, blanks and internal standards, was better than $\pm 10 \%$.

\section{RESULTS AND DISCUSSION}

The mosses watered with $\mathrm{Cd}$ showed a color change from light green (figure $2 \mathrm{~A})$ to yellowish-brown (Figure 2B). This phenomenon is so well documented like response to different causes: the phenolic compounds oxidation ${ }^{21}$; the alteration of chlorophyll; and the inhibition of chlorophyll synthesis ${ }^{2,23,24}$. An important effect on chlorophyll is the substitution of the $\mathrm{Mg}$ (II) by Cd (II) in its structure, which transforms the molecula into a feophytine, and the organism acquires a characteristic yellow-brown color ${ }^{22}$.

All biochemical events mentioned above should be associated to a response of plants to the environmental stress provoked by $\mathrm{Cd}^{22}$.
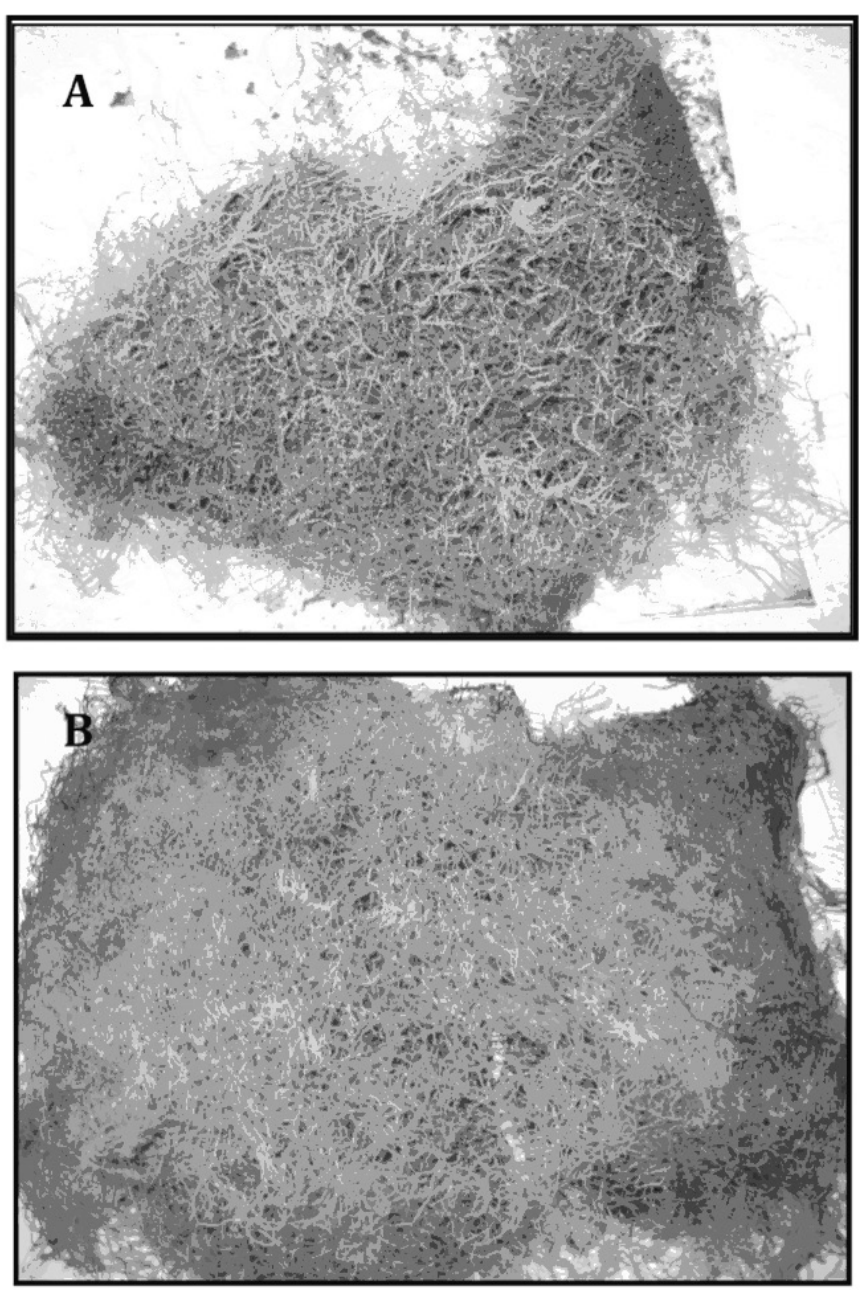

Figure 2: A: Mosses before Cd treatment, in laboratory conditions. B: Mosses treated with $\mathrm{Cd}, 12$ days after initiating the experiment. Chlorosis is observed, resulting from the inhibition of photosynthesis and the occurrence of yellowing of the plant treated with $\mathrm{Cd}$.

\section{Chromatography}

The chromatogram of the derivatization test showed the peaks corresponding to $\mathrm{N}$-acetyl-L-cysteine at $37.21 \mathrm{~min}$. join to the peaks of the derivatizing agent monobromobimane at 28.96 and $38.43 \mathrm{~min}$ (Figure 3A). These results demonstrated that the $\mathrm{SH}(\mathrm{s})$ groups of $\mathrm{N}$-acetyl-L-cysteine reacted with the monobromobimane, which validates its use with the moss samples since this compound unites with the $\mathrm{SH}(\mathrm{s})$ peptide residues extracted from them. Figure 3B shows the chromatogram with the glutathione standard, which showed a peak at $30.5 \mathrm{~min}$. 

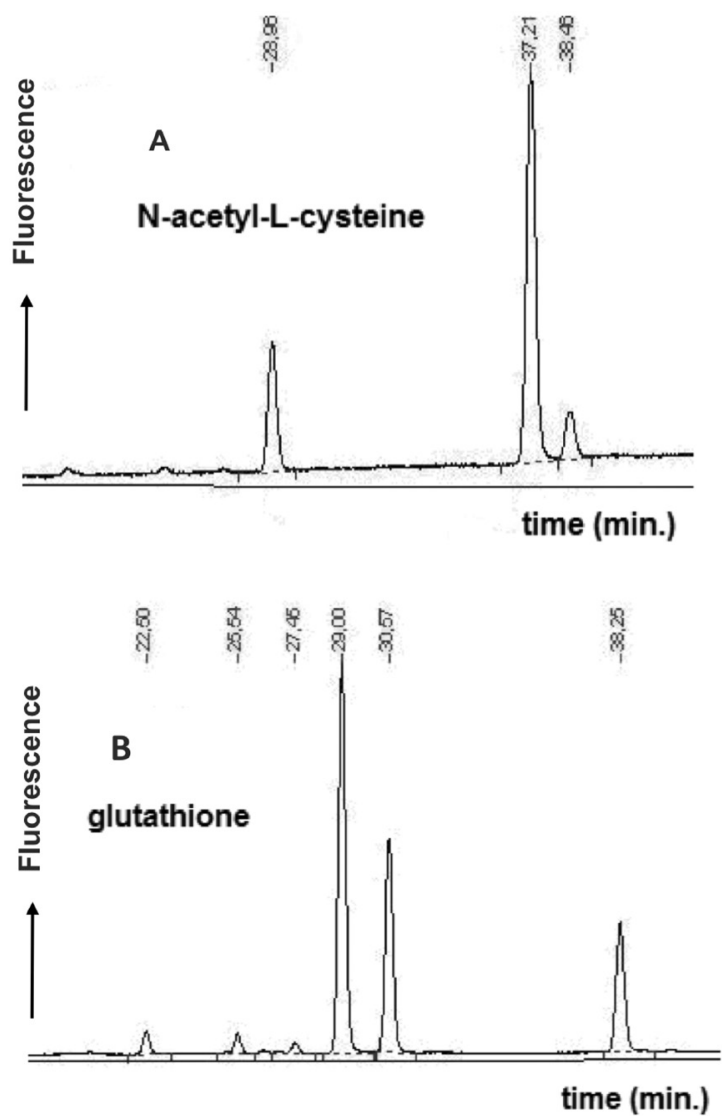

Figure 3: A: Chromatogram of the derivatizing agent probe and B: chromatogram of the glutathione standard, respectively.

Figure $4 \mathrm{~B}, \mathrm{C}$ and D shows the chromatograms of the samples of mosses treated with $\mathrm{Cd}$. The spectrum of the moss without $\mathrm{Cd}$ (Figure 4A) showed the peaks of monobromobimane, as well as a very small peak at $30.50 \mathrm{~min}$, the retention time of glutathione. The presence of this peak indicated that glutathione is a constitutive compound of the mosses analyzed. This means that it is always produced by the plant even in the absence of $\mathrm{Cd}$, since it has different functions in the cell; as an antioxidant compound, maintining the intracellular redox state and detoxifying xenobiotics and heavy metals by chelation ${ }^{25}$.
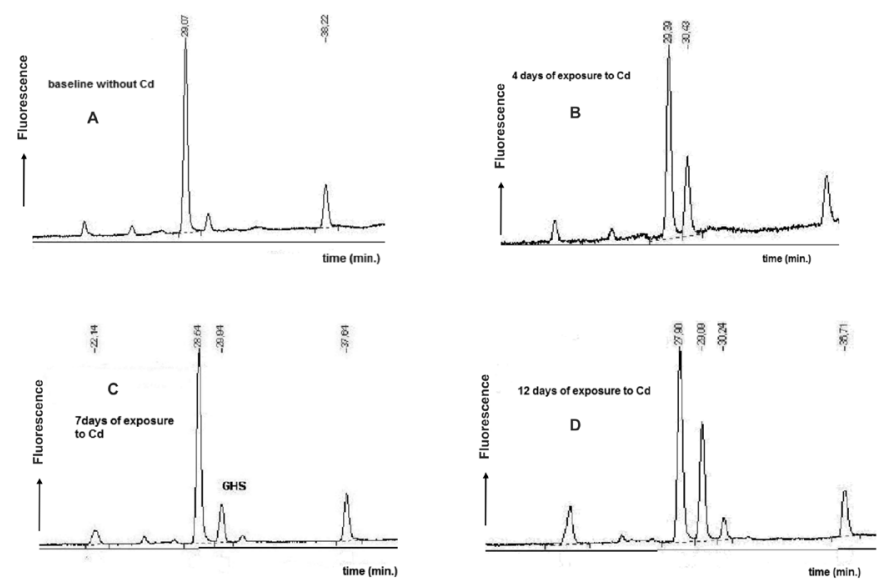

Figure 4: Chromatograms of mosses samples at A: day cero (0); B: 4 days; C: 7 days and D: 12 days after of the treatment with cadmium.
The chromatograms of mosses exposed to $\mathrm{Cd}$ for 4 to 12 days showed the same peaks corresponding to the retention time of glutathione (Figure $4 \mathrm{~B}, \mathrm{C}$ and $\mathrm{D}$ ). The progressive increase in the area under the curve of these peaks indicates that these plants increased their total cadmium content with more time of exposure to $\mathrm{Cd}$ (Table 1). Also, the peaks of the derivatizing agent were detected in these three chromatograms (Figure 4 B to D). As show in the Table 2 , the GSH content increased under Cd (II) stress.

Table 1: Areas under the glutathione curve obtained from chromatograms of mosses after 4,7 and 12 days of Cd exposition.

\begin{tabular}{|c|c|c|c|}
\hline Days of exposure to Cd & 4 days & 7 days & 12 days \\
\hline $\begin{array}{c}\text { Área of Glutathione } \\
\text { (relative \%) }\end{array}$ & 33.8 & 38.4 & 67.9 \\
\hline
\end{tabular}

Table 2: GSH mosses content after 4, 7 and 12 days of exposure at 100 $\mu \mathrm{mol} / \mathrm{L} \mathrm{Cd}$ (II) $[\mu \mathrm{g} / \mathrm{g} \mathrm{dw}]$. The values are means of three replicates.

\begin{tabular}{|c|c|c|c|}
\hline Days of exposure to Cd & $\mathbf{4}$ days & $\mathbf{7}$ days & 12 days \\
\hline$\mu \mathrm{g}$ GSH/g d.w. of moss & 0.16 & 6.25 & 11.25 \\
\hline
\end{tabular}

This result suggests that there was a stimulation of the synthesis of glutathione as a chelating agent of $\mathrm{Cd}$, which would trigger an antioxidant response to the stress provoked by the presence of this heavy metal in the tissues of the mosses. Glutathione has been described as a transitory chelating agent in bryophytes, since this compound is capable of transporting $\mathrm{Cd}$ to the vacuole of the cells, where it is stored and immobilized as $\mathrm{Cd}_{3}\left(\mathrm{PO}_{4}\right)_{2}^{5,11}$.

The appearance of a peak with a retention time of 31 minutes in the chromatogram of the samples with 7 days of Cd exposure (Figure $4 \mathrm{C}$ ), after the peak of GSH at 30 minutes, suggests the presence of another thiolic compound, which might be a precursor of GSH, for example $\gamma$-EC ( $\gamma$-glutamil cisteine). This compound has been described as a precursor of glutathione. Sneller and col. ${ }^{18}$ and Rijstenbil and col. ${ }^{19}$ reported the presence of a peak next to that of glutathione, which was identified as $\gamma$-glutamil cisteine using a standard of this compound.

\section{Determination of $\mathrm{Cd}$ in bryophytes.}

The concentration of $\mathrm{Cd}$, measured in dry plant material, increased from $13.6 \mu \mathrm{g} / \mathrm{gr}$ (d.w) at day 0 of the experiment to $35.6 \mu \mathrm{g} / \mathrm{gr}$ (d.w.) at day 4 and $40.3 \mu \mathrm{g} / \mathrm{gr}$ (d.w) at day 7. However, at day 12 the Cd concentration decreased to $31.3 \mu \mathrm{g} / \mathrm{gr}$ (d.w.).

On other hand, since cadmium is not an essential element for plants ${ }^{26}$, the increase of $\mathrm{Cd}$ (II) during the course of the experiment (Table 3) must be associated with the bio-accumulation of this element. This agrees with other reports in the literature $5,11,12,13,15,16,27$ which have documented the capacity of mosses to sequester heavy metals when they are in high concentration in the environment. The decrease of Cd (II) concentration observed on day 12 of the experiment is counter to the expected bio-accumulation, which suggests a possible effect of loss of efficiency or saturation of the enzymatic bioaccumulation machinery ${ }^{28}$. As with any enzyme kinetics, the bio-accumulation of heavy metals has a saturation point ${ }^{28}$.

Table 3: Concentration of $\mathrm{Cd}$ in $\mu \mathrm{g} / \mathrm{g}$ (d.w.) of moss plants exposed for $0,4,7$ and 12 days.

\begin{tabular}{|c|c|c|c|c|}
\hline Days of exposure to Cd & O days & $\mathbf{4}$ days & $\mathbf{7}$ days & $\mathbf{1 2}$ days \\
\hline $\mathrm{Cd}, \mu \mathrm{g} / \mathrm{g}$ (d.w.) & 13.6 & 35.6 & 40.3 & 31.3 \\
\hline
\end{tabular}

These results suggest a good correlation between accumulation of glutathione and the Cd content in plants; which could indicate the chelation process was carried out by this peptide.

The results obtained here indicate the absence of the phytochelatin type of chelating agents in bryophytes submitted to Cd (II) stress. This agrees with other reports which have studied bryophytes in similar experimental conditions 5,11. Preliminary results from our laboratory using PCR analysis indicated that the phytochelatin synthase gene, should be absent in plants of Thuidium sp. 
(unpublished data). Therefore, not expression of the phytochelatin synthesis should be expected in this kind of plants.

Based upon the results obtained here, the oligopeptide glutathione appears to have a fundamental role in the bio-accumulation of cadmium in bryophytes. This seems to be the most relevant mechanism in the response of these plants to the stress caused by cadmium.

\section{CONCLUSIONS}

The exposure of mosses to cadmium for a period of 12 days induced the synthesis of glutathione, which showed a steady increase during the experimental period. Also, we observed the appearance of an unidentified compound that presumably corresponded to $\gamma$-EC.

We did not detect the appearance of phytocheatins in response to stress by cadmium. This result corroborates previous studies in indicating that in case of bryophytes, only glutathione and their precursors, cysteine and $\gamma$-EC, are involved in the process of chelation of heavy metals.

The analysis conducted by Atomic Absorption, shows the availability of these plants to bioacumulate cadmium. We detect a saturation point in this process through the cessation of $\mathrm{Cd}$ accumulation towards the end of the experimental period.

Through the confirmation of the ability of some endemic mosses (Thuidium sp.), to bioacumulate heavy metals through a chelation process, this work contributes to the realization of the use of bryophytes as biomonitors in environmental contamination.

\section{ACKNOWLEDGMENTS}

The authors are grateful to Dr. Victor Kesternich, for his critical reading of the manuscript. Other acknowledgments, to Dr. Javier Palacios for his technical support in this work.

\section{REFERENCES}

1. Sauge-Merle, S., Cuiné, S., Carrier, P., Lecomte-Pradines, C., Iuu, D. and Gilles, P. Enhanced toxic metal accumulation in engineered bacterial cells expressing Arabidopsis thaliana Phytochelatin Synthase. Appl. Environ. Microbiol. 69, 490 (2003).

2. Clemens, S. Toxic metal accumulation, responses to exposure and mechanism of tolerance in plants. Biochimie. 88, 1707 (2006).

3. Cobbet, C.. Phytochelatins and their roles in heavy metal detoxification. Plant. Physiol. 123, 825 (2000).

4. Gisbert, C., Ros, R., De Haro, A., Walker, D., Bernal, M., Serrano, R. and Aviñó, J.N. A plant genetically modified that accumulates $\mathrm{Pb}$ is especially promising for phytoremediation. Biochem. Biophys. Res. Commun. 303, 440 (2003).

5. Bleuel, C., Wesenberg, D., Sutter, K., Miersch, J., Braha, B., Barlocher, F., and Krauss, G. The use of the aquatic moss Fontinalis antipyretica L. ex Hedw. as a bioindicator for heavy metals $3 . \mathrm{Cd}^{2+}$ accumulation capacities and biochemical stress response of two Fontinalis species. Sci. Total Environ. 345, 13 (2005).

6. Guzmao, A. Cacoilo, S., Almeida, E. Glutathione-mediated cadmium sequestration in Rhizobium leguminosarum. Enzyme Microb. Technol. 39, 763 (2006).

7. Gstoettner, and Fisher, N. Accumulation of Cadmium, Chromium, and Zinc by the moss Sphagnum Papillosum Lindle. Water Air Soil Pollut. 93, 321 (1997).

8. Ha, S-K., Smith, A., Howden, R., Dietrich, W., Bugg, S., O'conell, M.J., Goldsbrough, P.B. \& Cobbett, C.S. Phytochelatin synthase genes from Arabidopsis and the yeast Schizosaccharomyces pombe. The Plant Cell. 11, 1153 (1999).
9. Hirata, H., Tsuji, N. and Miyamoto K.. Biosynthetic regulation of phytochelatins, heavy metal-Binding Peptides. J. Biosci. Bioeng. 100, 593 (2005).

10. Rauser, W. Phytochelatins and related peptides. Plant Physiol. 109, 1141 (1995).

11. Bruns, I., Sutter, K., Menge, S., Neumann D. and Krauss, G. Cadmium lets increase the glutathione pool in bryophytes. J. Plant Physiol. 158, 79 (2001).

12. Clemens, S. Evolution and function of phytochelatin synthases. J. Plant Physiol. 163, 319 (2006).

13. Caballeira., A. and Fernandez, J. Bioconcentration of the moss Scleropodium purum in the area surrounding a power plant A geotopographical predictive model for mercury. Chemosfere. 47, 1041 (2002).

14. Ike, A., Sriprang, R., Ono, H., Murooka, Y and Yamashita, M. Bioremediation of cadmium contaminated soil using symbiosis between leguminous plant and recombinant rhizobia with the MTL4 and the PCS genes. Chemosphere. 66, 1670 (2007).

15. Szarek-Lukaszewska, G., Grodsinska, K. and Braniewski, S. Heavy metal concentration in the moss Schreberi In the Niepolomice forest, Poland: changes During 20 Years. Environ. Monit. Assess. 79, 231 (2002).

16. Aboal, J., Fernández, J. and Carballeira, A. Sampling optimization, at site scale, in contamination monitoring with moss, pine and oak. Environ. Pollut. 115, 313 (2001).

17. Rui Figueira, R., and Ribeiro, T. Transplants of aquatic mosses as biomonitors of metals released by a mine effluent. Environ. Pollut. 136, 293 (2005).

18. Sneller, F., Heerwaarden, L., Koevoets, P., Vooijs, R., Schat, H. and Verklej, J. Derivatization of Phytochelatins from Silene vulgaris, induced upon Exposure to Arsenate and Cadmium: Comparasion of Derivatization with Ellman s Reagent and Monobromobimane. J. Agric. Food. Chem. 48, 4014 (2000).

19. Rijstenbil, J. and Wijnholds, J. HPLC analysis of nonprotein thiols in planktonic diatoms: pool size, redox state and response to copper and cadmium exposure. Mar. Biol. 127, 45 (1996).

20. Quattrochi, O. et al. Introducción a la H.P.L.C. Aplicación y práctica. Capitulo 10. Argentina, Artes Gráficas S.A. 407p. (1992).

21. Mayer, A. Polyphenol oxidases in plants and fungi: Going places? A review. Phytochem. 67, 2318 (2006).

22. Cabrera, S. Estimación de la concentración de clorofila a y feopigmentos. Una revisión metodológica. En: Embalses Fotosíntesis y Productividad Primaria. Chile. Nibaldo Bahamonde y Sergio Cabrera. 236p. (1983).

23. Arora, A., Sairam, R. and Srivastaba, G. Oxidative stress and antioxidative system in plants. Curr. Sci. 82, 1227 (2002).

24. Clemens, S., Kim, J., Neumann, D. and Schroeder, J. Tolerance to toxic metals by a gene family of phytochelatin synthases from plants and yeast. J.EMBO j. 18, 3325 (1999).

25. Moreno, S., Martinez, J. and Mendoza, D. Efecto del Cadmio sobre el Metabolismo del Glutation en Euglena gracilis. En: XIV Congreso de Bioenergéticas y Biomembránas: 13 al 18 de Noviembre de 2005. Oxaca, Mexico, Sociedad Mexicana de Bioquímica A.C. (2005).

26. Ekmeckci, Y., Tanyolac, D. and Ayhan, B. Effects of cadmium on antioxidant enzyme and photosynthetic activities in leaves of two maize cultivars. J.Plant Physiol. 165, 600 (2008).

27. Zechmeister, H., Hohenwallner, D., Riss, A. and Hanus-Illnar, A. Variations in heavy metal concentrations in the moss species Abietinella abietina (Hedw.) Fleisch. According to sampling time, within site variability and increase in biomass. Sci. Total Environ. 310, 55 (2002).

28. Murray, R., Granner, D., Mayes, P. and Rodwell, V. Bioquímica de Harper. $15^{\mathrm{a}}$ ed. Editorial, Manual Moderno, pag. 1041, (2001). 